Dept. of Biochemistry,

Animal Health Research Institute, El-Mansoura Lab.

\title{
CHEMICAL AND MICROBIOLOGICAL EVALUATION OF SOME MARKETED SALTED FISH IN MANSOURA
}

(With 3 Tables)

\author{
By \\ AZZA E.A. HASSAN and
}

(Received at 23/8/2011)

\section{التقييم الكيميائي والبكتريولوجي لبعض الأسماك المملحة المعروضة بالأسواق في المنصورة الإنيمات}

$$
\text { عزة السبي على حسان ، وئسام باهر }
$$

أجريت هذه الدراسة لتقييم الأسماك المملحة المعروضة للبيع بأسواق المنصورة كيميائيا

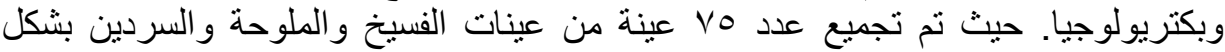

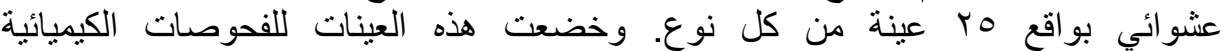

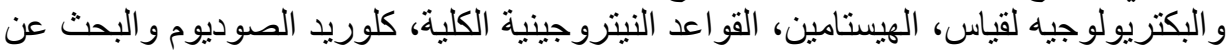

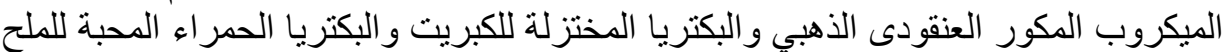

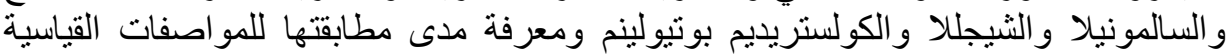

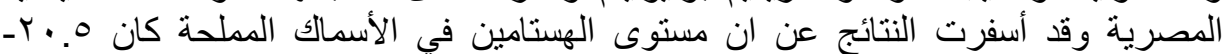

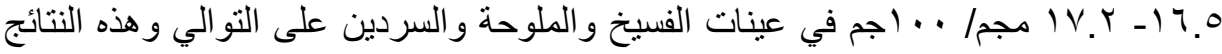

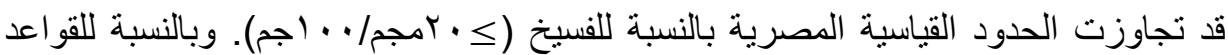

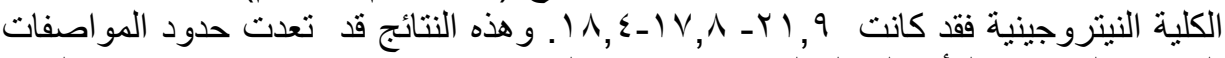

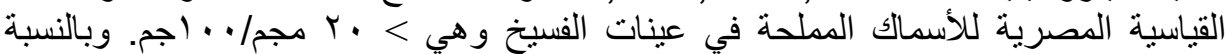

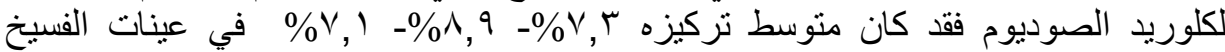

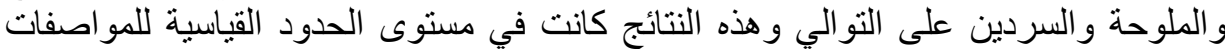

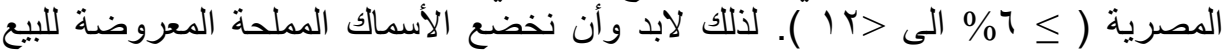

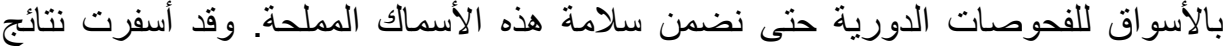

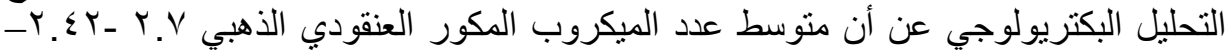

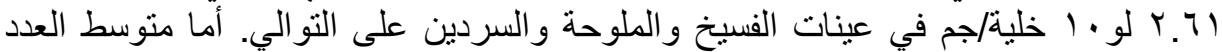

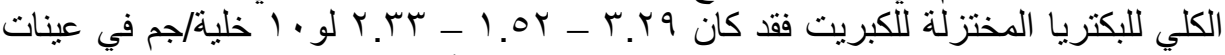

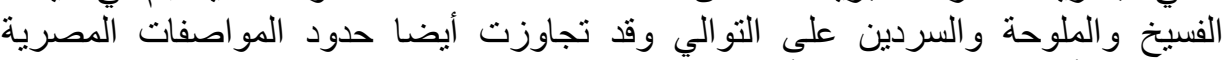

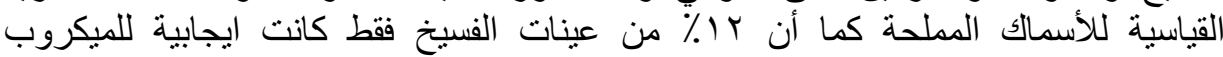

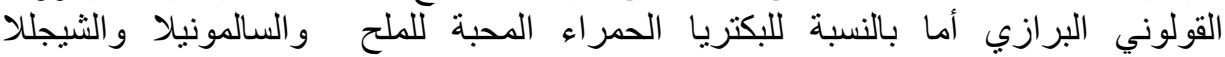




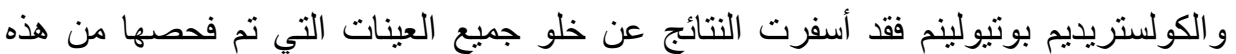

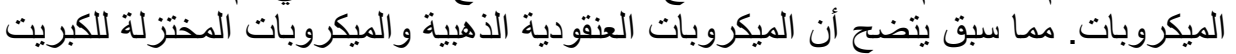

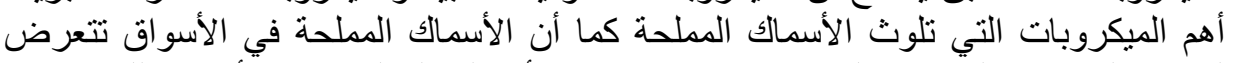

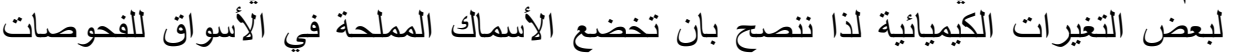
الكيميائية و البيكتريولوجية بصفة دورية.

\section{SUMMARY}

This study was carried out to evaluate chemically and bacteriologically the marketed salted fish in Mansoura. A total of 75 samples were collected randomly from Fesiekh, Melouha and Sardine (25 of each) from Mansoura markets. The samples were chemically and bacteriologically examined. The results revealed that the mean histamine levels in the examined samples were $21.5,16.5 \mathrm{and} 17.2 \mathrm{mg} / 100 \mathrm{gm}$ Fesiekh, Melouha and Sardine respectively and these results exceeded the permissible limit of histamine of the Egyptian Standard Organization in Fesiekh $(\leq 20 \mathrm{mg} / 100 \mathrm{gm})$. More over the mean TVBN in the examined samples were 21.9, 17.8and $18.4 \mathrm{mg} / 100 \mathrm{gm}$ of Fesiekh, Melouha and Sardine respectively. Concerning sodium chloride concentration in the examined salted samples the means were $7.3 \%$, $8.9 \%$ and $7.1 \%$ for Fesiekh, Melouha and Sardine respectively. These results were within the permissible limit $(\geq 6 \%<12 \%$.). Meanwhile the bacteriological examination showed that the mean count of Staph. aureus in Fesiekh, Melouha and Sardine samples were 2.7, 2.42 and $2.61 \log _{10}$. c.f.u/gm respectively, which exceeded the Egyptian standard limits of Staph. aureus count in salted fish. Regarding sulphite reducing anaerobic bacteria their means were $3.29,1.52$ and $2.33 \log _{10}$ c.f.u/gm which exceeded the Egyptian standard limits. In addition E. coli was present in $12 \%$ of Fesikh samples only, but red halophilic bacteria, salmonellae shigellae and Clostridium botulinum were not detected in any sample. From the mentioned above, we can conclude that the examined salted fish in the markets were exposed to chemical changes and bacterial contamination so the salted fish in the markets must be examined chemically and bacteriologically frequently to ensure the safety of the product.

Key words: Fish, salted fish, S.aureus, anaerobes, histamine, TVBN.

\section{INTRODUCTION}


Consumption of fish is recommended because it is a good source of high quality protein, minerals, vitamins and omega -3 polyunsaturated fatty acids. which have proved to protect consumers against coronary heart disease reducing arrhythmias and thrombosis (Kris-Etherton et al., 2002), reducing the risk of heart attack and sudden death (Jarvinen et al., 2006), lowering plasma triglyceride levels and reducing blood clotting tendency (Ismail, 2005) and high blood pressure (Harris, 1997). Moreover, the intake of fish has shown benefits in children's growth and in diseases such as rheumatoid arthritis (Rahman et al., 2008); psychiatric disorders and lung disease (Cerchietti et al., 2007).

Salting is a method of preservation of fish and salted fish constitute an important part of the diet of great portion of consumers and have subjected to many risks (Kassem, 1996). Salting of fish develops a desirable flavor where presentation of fish by salting and fermentation could not be separated, since both were involved to a varying degree in most practical processes (Hobbs, 1987).

Salted fermented fish as Fesiekh, Melouha and salted sardine are among the popular fish products available in Mansoura City such products could be consumed on large scale ring some occasions and feasts.

The first stage of salting processes is the addition of salt to the raw fish. Then fish is stored in sealed barrels or containers at ambient temperatures. Fesiekh is a semi putrid form of salted and dried fish. The traditional process of preparing it is to dry the fish in the sun for som days before being preserved in salt. Melouha is prepared from a fresh water fish (El-Sheshnagui, 2006). Histamine amounts in fish depend on production date and increases by closing to expiration date of samples. For the safety of food and consumers protection from food borne diseases various organisms used as an index of sanitary quality of food products such as E. coli and staphylococci (Mousa, 1986).

The shelf-life of processed fish should be longer than that of fresh raw products especially when stored anaerobically (Sofas, 1994). In Egypt, an outbreak of food intoxication has been recorded due to consumption of inadequate prepared salted fermented fish (Fesiekh) (Rakha, 1992). Pathogenic micro-organisms can contaminate fish products during production in fish processing factories (Hanna et al., 2003).

Sensory quality is influenced not only by microbial activity but 
also by chemical substances such as salt preservative and biochemical changes in lipid composition during storage causing rancidity (Kaitaranata, 1982).

$\mathrm{Cl}$. perfringens has been implicated in many food poisoning outbreaks in American food (Wen and Maciane, 2004; Hosseini et al., 2009). Salted fish is considered a public health hazard. In some instances salted fish in Egypt may be prepared under poor hygiene and unsafe conditions, which have been resulted in human illness (El-Sheshnagui, 2006). Fish in its natural environment has its own micro- flora in the slime, on its body, in its gut and gills. These micro-organisms, as well as the enzymes in the tissues of the fish, bring about putrefactive changes in fish when it died. Furthermore, the micro-organisms generally present in the salt used for salting also contribute to the degradative changes in the fish (Essuman, 1992). In case of poor hygiene, the contamination of salted fish may increase due to the unsanitary procedures during processing and handling (Novotny et al., 2004).

The chemical and bacteriological quality of salted fish (Fesiekh, Melouha and sardine) as the product must have salt concentration $\geq 6 \%$, free from the pathogenic bacteria and its toxins, the Red halophils., Clostridium botulinum and Escherichia coli. Also the counts of Staphylococcus aureus and total sulfited reducing anaerobic bacteria must be $\leq 10^{2}$ c.f.u. $/ g$. (EOSQC, 2010). So the aim of the present study was to assess the chemical quality of Fesiekh, Melouha and Salted Sardine exposed for sale in Mansoura markets in accordance to the Egyptian Organization for Standardization and quality control specifications (EOSQC, 2010), regarding of histamine, total volatile basic nitrogen, sodium chloride, Staphylococcus aureus, sulphite reducing anaerobic bacteria, red halophilic bacteria, salmonellae shigellae and Clostridium botulinum.

\section{MATERIALS and METHODS}

A total of 75 samples of salted fish, 25 each of Fesikh, Melouha and Sardine were randomly collected from Mansoura markets and transferred directly to the laboratory. The skin and bones of the salted fish were removed and the muscle was comminuted using a sterile blender jar. The prepared samples were subjected to the following examination:

\section{1 - Sensory evaluation.}




\section{2 - Chemical analysis:}

a. Determination of histamine was done using liquid chromatography as described by Beljaars et al. (1998) and AOAC (1990).

b. Determination of total volatile basic nitrogen (TVBNmg/100gm) was done according to FAO (1980).

c. Determination of sodium chloride content was done as described in Codex Stan (2005).

\section{3 - Bacteriological analysis:}

Decimal serial dilutions of samples were prepared and inoculated to differential reinforced clostridia medium (OXOID CM 149) and Baird Parker Agar (OXOID CM 275) by pour plate method for sulphite reducing anaerobic bacteria and Staphylococcus aureus count, respectively.

The methods outlined by Karl (2005) was followed for detection and identification of red halophilic bacteria.

Samples were examined also for the presence of Salmonella and Shigellae on X L D agar. Vibrio parahaemolyticus on TCBS agar, Clostridium botulinum on Reinforced Clostridial Medium and E.coli on Eosine methylene blue agar.

Isolated bacteria were identified and confirmed biochemically as described by Harrigan (1998).

Statistical analysis was carried out following the method described by Kirkwood (1989).

\section{RESULTS}

Table 1: The mean histamine, total volatile basic nitrogen and sodium chloride levels of the examined salted fish samples $(n=25$ of each).

\begin{tabular}{|c|c|c|c|}
\hline $\begin{array}{c}\text { Parameters } \\
\text { Salted fish }\end{array}$ & $\begin{array}{c}\text { Histamine level } \\
(\mathrm{mg} / 100 \mathrm{gm})\end{array}$ & $\begin{array}{c}\text { TVBN } \\
(\mathrm{mg} / 100 \mathrm{gm})\end{array}$ & $\begin{array}{c}\text { Sodium chloride } \\
\%\end{array}$ \\
\hline \multirow{2}{*}{ Fesiekh } & 20.5 & 21.9 & 7.3 \\
& \pm 2.2 & \pm 2.1 & \pm 0.8 \\
\hline \multirow{2}{*}{ Melouha } & 16.5 & 17.8 & 8.9 \\
& \pm 1.8 & \pm 1.6 & \pm 0.9 \\
\hline \multirow{2}{*}{ Sadine } & 17.2 & 18.4 & 7.1 \\
& \pm 1.9 & \pm 1.5 & \pm 0.6 \\
\hline
\end{tabular}

The permissible limits of histamine and TVBN $\leq 20$ 
Table 2: Counts of Staphylococcus aureus and Sulphite reducing anaerobic bacteria in the examind salted fish samples $(\mathrm{n}=$ 25 of each)

\begin{tabular}{|c|c|c|c|c|c|c|}
\hline \multirow{2}{*}{ Bacteria } & \multicolumn{3}{|c|}{$\begin{array}{c}\text { Staphylococcus aureus } \\
\left(\log _{10} \text { c.f.u/g) }\right.\end{array}$} & \multicolumn{3}{c|}{$\begin{array}{c}\text { Sulphite reducing } \\
\text { anaerobic bacteria } \\
\left(\log _{10} \text { c.f.u/g) }\right.\end{array}$} \\
\cline { 2 - 7 } & Min & Max & $\begin{array}{c}\text { Mean } \pm \\
\text { SE }\end{array}$ & Min & Max & $\begin{array}{c}\text { Mean } \pm \\
\text { SE }\end{array}$ \\
\hline $\begin{array}{c}\text { Fesiekh } \\
\text { ( Mugil cephalus) }\end{array}$ & 1.27 & 4.53 & $\begin{array}{c}2.7 \\
\pm 0.4\end{array}$ & 1.73 & 1.73 & $\begin{array}{c}3.29 \\
\pm 0.70\end{array}$ \\
\hline $\begin{array}{c}\text { Melouha } \\
\text { (Hydrocyons froskalii) }\end{array}$ & 1.3 & 3.93 & $\begin{array}{c}2.42 \\
\pm 0.23\end{array}$ & 1.6 & 1.6 & $\begin{array}{c}1.52 \\
\pm 0.35\end{array}$ \\
\hline $\begin{array}{c}\text { Sardine } \\
\text { (Sardina pilchardus) }\end{array}$ & 1.42 & 4.11 & 2.61 & 1.6 & 1.6 & $\begin{array}{c}2.33 \\
\pm 0.27\end{array}$ \\
\hline
\end{tabular}

Table 3: Incidence of bacteria isolated from the examined salted fish samples $(\mathrm{n}=25$ of each)

\begin{tabular}{|c|c|c|c|c|c|c|}
\hline \multirow{2}{*}{ Bacteria } & \multicolumn{2}{|c|}{$\begin{array}{c}\text { Fesiekh } \\
\text { ( Mugil cephalus) }\end{array}$} & \multicolumn{2}{c|}{$\begin{array}{c}\text { Melouha } \\
\text { Hydrocyons } \\
\text { froskalii) }\end{array}$} & \multicolumn{2}{c|}{$\begin{array}{c}\text { Sardine (Sardina } \\
\text { pilchardus) }\end{array}$} \\
\cline { 2 - 7 } & $+\mathrm{ve}$ & $\%$ & $+\mathrm{ve}$ & $\%$ & $+\mathrm{ve}$ & $\%$ \\
\hline $\begin{array}{c}\text { Staphylococcus } \\
\text { aureus }\end{array}$ & 15 & 60 & 10 & 40 & 12 & 48 \\
\hline $\begin{array}{c}\text { Sulphite reducing } \\
\text { anaerobic bacteria }\end{array}$ & 14 & 56 & 9 & 36 & 11 & 44 \\
\hline $\begin{array}{c}\text { Red halophillic } \\
\text { bacteria }\end{array}$ & 0 & 0 & 0 & 0 & 0 & 0 \\
\hline $\begin{array}{c}\text { Clostridium } \\
\text { botulinum }\end{array}$ & 0 & 0 & 0 & 0 & 0 & 0 \\
\hline E-coli & 3 & 12 & 0 & 0 & 0 & 0 \\
\hline Salmonellae & 0 & 0 & 0 & 0 & 0 & 0 \\
\hline Shigellae & 0 & 0 & 0 & 0 & 0 & 0 \\
\hline
\end{tabular}




\section{DISCUSSION}

Fish have been in an over whelping majority of the incidence of histamine poisoning, the so called Scombroid fish so fish is the most commonly implicated in histamine poisoning (Rodriguez et al., 1994). Histamine production in fish and other foods is by the decarboxylation of histidine through a reaction catalyzed by the enzyme histidine decarboxylase. It is reported, however that the decarboxylation reaction results largely from the fermentation of fish which are a likely source of histamine (Ababouch et al., 1991). Table 1 showed that the mean histamine levels in the examined salted fish samples were 20.5, 16.5 and 17.2 for Fesiekh, Melouha and Sardine samples respectively. These results (fesiekh) had been exceeded the Egyptian standard limit of histamine in salted fish $(\leq 20 \mathrm{mg} / 100 \mathrm{~g})$. Higher results were reported by (Kassem, 1996; Gehad, 2005). Lower findings (18.3 mg/ $100 \mathrm{gm}$ muscle) were recorded by Samaha et al. (1997) and higher finding also for sardine was stated by Riad (1997), who reported that the mean value of histamine level was $19.25 \mathrm{mg} / 100 \mathrm{gm}$ muscle However, all the examined.

The USA Food and Drug Administration (FDA), for instance established a hazard action level (HAL) of $50 \mathrm{mg} / 100 \mathrm{~g}$ in tuna products based on the investigation of previous histamine poisoning outbreaks and the defect action level (DAL) of $20 \mathrm{mg} / 100 \mathrm{~g}$. Peconek et al. (1997) indicated that during storage of salted herring at ambient temperature the increase of histamine content in their flesh. While Fonberg-Broczek et al. (2003), found that the histamine content increased in low-salted sampled up to $35 \mathrm{~g} / \mathrm{kg}$ during the period of storage.

Taylor et al. (1989) stated that histamine formation in fish can be prevented by proper handling and refrigerated storage. Hosseini et al. (2009) revealed that histamine amounts depend on the production date and increase by closing to expiration date of samples. Regarding TVBN in the examined salted fish, Table 1 showed that the mean levels in Fesiekh, Melouha and Sardine were 21.9, 17.8 and $18.4 \mathrm{mg} / 100 \mathrm{gm}$, respectively Such increase may be partly attributed to the production of volatile basic compounds as ammonia (Galli et al., 1993). Nearly similar results were obtained by Acuff et al. (1984); Barile et al. (1985). These results exceeded the permissible limits of TVBV in Fesiekh on the other hand Table 1 showed that the mean salt percentages (sodium chloride 
percentages) of the examined salted fish samples were 7.3, 8.9 and 7.1 for Fesiekh, Melouha and Sardine respectively, which were within the permissible limit not less than $6 \%$ as recommended by EOSQC (2005). The current study was in agreement with Gimenez and Dalgarad (2004).

Salt preserves fish by the removal of water from the flesh to a level that impedes microbial growth and enzymatic activities. The reduced use of salt results in uncontrolled fermentation. Under such conditions the fish muscle becomes ideal for the growth of pathogenic organisms and the product may decay within a short period. In situations where brine is reused a number of times, the chemical composition of the salt solution is altered (ICMSF, 1980). Products with high moisture content tend to deteriorate faster than drier products especially if the salt level is low (FDA, 2001).

The above results showed an increase in histamine and TVBN levels, while sodium chloride contents were within the permissible limits according to EOSQC (2005). So the salted fish in the market must be put under continuous examination to ensure the safety of the salted fish and to exclude the hygienic product.

Regarding bacteriological examination Table 2 revealed that the mean counts of Staph. aureus in Fesiekh, Melouha and Sardine samples were 2.7, 2.42 and $2.61 \log 10 \mathrm{c} \mathrm{f} \mathrm{u} / \mathrm{g}$ respectively, which exceeded the Egyptian standard limits of Staph. aureus count in salted fish. Presence of Staphylococcus aureus may be attributed to food handlers and equipment Forbes et al. (1998). Nearly similar results were recorded by Kassem (1996). Higher results were obtained by El-Kewaiey (2001). In addition higher results were stated by Basti et al. (2004).

Table 2 showed that the mean counts of suplhite reducing anaerobic bacteria were $(3.29,1.52$ and 2.33) $\log 10 \mathrm{c} \mathrm{f} \mathrm{u} / \mathrm{g}$ Fesiekh, Melouha and Sardine samples respectively. The obtained results exceeded the Egyptian standard limits of sulphite reducing anaerobic bacteria count.

Moreover red halophilic bacteria were not detected in all the examined samples (Table 2). Similar results were obtained by Krieg and Holt; (1984). Higher results were recorded by Gram and Huss (1996), they stated that fish products with high salt contents may spoil due to growth of halophilic bacteria. The red halophilic bacteria causes the pink slime on the surface of salted sigh which gradually spread leading to sigh degradation due to the active proreolytic enzymes produced by 
bacteria, these bacteria belong to two genera of bacteria namely Halobacterium and Holococcus. Halobacterium is rod-shaped requiring at least $10-15 \%$ salt concentration for growth. Halococcus can thrive at $5-10 \%$ salt content. Both genera are growing optimally at $37 \mathrm{C}^{\circ}$ and produce red carotenoid pigments (Krieg and Holt 1984).

In the present study salmonellae, shigellae and Clostridium botulinum were not detected in any sample which were in agreement with Basti et al. (2004)

From the above results we can concolude that Staph. aureus, and sulphite reducing anaerobic bacteria are very important contaminats of salted fish from Mansoura markets, the processing methods of salting fish particularly Fesiekh could creat avenues for microbial infection and risks of food poisoning. This could be attributed to the microbiological status of additives used by different classes of factories using common salts of low quality and poor hygienic measures. Evisceration must be performed to minimize contamination of fish flesh.

\section{REFERENCES}

Ababouch, L (1991): Identification of histamine-producing bacteria isolated. From Sardine (Sardina Pilchardus) stored in ice and at ambient temperature $\left(25^{\circ} \mathrm{C}\right)$. Food Microbiology, 8(2): 127-136.

Acuff, G.; Izat, A.I. and Finne, G. (1984): Microbial flora of reared Tilapia held on ice. J. Food. Protect. 47: 778-780.

AOAC "Association of Official Analytical Chemists" (1990): Official Methods of Analysis, $15^{\text {th }}$ Ed. USA.

Barile, L.E.; Milla, A.D.; Reilly, A. and Villadsen, A. (1985): "Spoilage patterns of mackerel." "FAO Fisheries Rep. No. 317, pp. 23-40.

Basti, A.A.; Misaghi, A.; Salehi, A.Z. and Kamkar, A. (2004): Bacterial pathogens in fresh, smoked and salted Iranian fish. J. Food Prot., 67 (5): 960-965.

Beljaars, P.R.; Remmelt, V.D.; Klaas, M.J. and Louis, J.S. (1998): Liquid chromatographic detection of histamine in fish, sauerkraut and wine: Inter-laboratory study. J. AOAC International 81(5): 991-998.

Cerchietti, L.C.; Navigante, A.H. and Castro, M.A. (2007): Effects of eicosapentaenoic and docosahexaenoic $\mathrm{n}-3$ fatty acids from fish oil and preferential Cox -2 inhibitions on systemic syndromes in 
patients with advanced lung cancer. Nutr. Cncer 59: 14-20.

Codex Stan (2005): Codex Standard for Salted Fish and Dried Salted Fish of the Gadidae Family of Fishes. 167-1989- Rev. 2

El-Kewaiey, I.A. (2001): Quality assessment some local manufactured and retailed meat and fish products. Ph.D. Thesis Vet. Med. Sci. Faculty of Vet. Med. Kafr El-Shiekh, Tanta Univ.

EL-Sheshnagui, M.L. (2006): Sanitary evaluation of some salted fishes in Alexandria. Assiut Vet. Med. J. 52: 96-110.

EOSQC (2005): Egyptian Organization for Standardization and Quality Control. ESS. 1725-1,2,3/ 2005, for Salted Fishes.

EOSQC (2010): The Egyptian Organization for Standardization and Quality Control. ESS for Salted Fish.

Essuman, K.M. (1992): Fermented fish in Africa. A study on processing, marketing and consumption. FAO Fisheries Technical Paper 392.

FAO (1980): Manual of Food Quality Control IV Microbiological analysis "FAO" United Nations, Rome. Tech. Res. Ser.

FDA (2001): Clostridium Toxin Formation. Ch. 13. In Fish and Fishery Products Hazards and Controls Guidance, $3^{\text {rd }}$ Ed. P. 167-190. Food and Drug Administration, Center for Food Safety and Applied Nutrition, Office of Sea Food, Washington, DC.

Fonberg-Broczek, M.; Sawilska-Rautenstrauch, D.; Windga, B.; Sciezyska, H.; Jerda, M.; Badwski, P. and Urbanek-Karowska, B. (2003): The content of histamine and tyramine dependent of microbiological quality of salted herring stored at different tepmrature. Rocz Panstw Zakl Hig, 54 (1): 87-95.

Forbes, B.A.; Sahm, D.E. and Weissfeld, A.S. (1998): Diagnostic Microbiology $10^{\text {th }}$ Ed. Mosby, Inc. 11830 West line.

Galli, A.L.; Franzetti, S.; Garelli, L.; Piergiovanni and Fava, P. (1993): "Microbiological quality and shelf life of chilled Cod fillets in vacuum-skin and modified atmosphere packaging." Pack. Technol. Sci., 6: 147-157.

Gehad, F.A. (2005): Health hazard associated with salted fish in Egyptian markets. Egyptian Journal of Agricultural Research. 83, 1: 405-414.

Gimenez, B. and Dalgarad, P. (2004): Modeling and predicting the simultaneous growth of listeria monocytogenes and spoilage microorganisms in cold-smoked salmon. J. Appl. Microbiol. 96: 96-109.

Gram, L. and Huss, H.H. (1996): Microbiological spolilage of fish and fish products. Int. J. Food Microbiol. 33 (1): 121-137. 
Hanna, M.; Anne, A.; Tina, L. and Gun, W. (2003): Prevalence of Listeria monocytogens, microbiological and sensory quality of rainbow trout and white fish from finis h retail markets. J. Food Protec. 66 (10): 1832-1839.

Harrigan, W.F. (1998): Fish, Shellfish and Crustacea. In Laboratory Methods in Food Microbiology, $3^{\text {rd }}$ Ed., San Diego, London, Boston, New York, Sydney, Tokyo, Toronto. Pp: 191-233.

Harris, W.S. (1997): N -3 fatty acids and serum lipoproteins: human studies. Am. J. Clin. Nutr., 65: 16455-16545.

Health hazard associated with salted fish in Egyptian markets. Egyptian Journal of Agricultural Research. 83,1: 405-414.

Hobbs, G. (1987): Microbiology of fish. Essay in Agriculture and food Microbiology. Edited by Norris, J.R. and Pettiphen G.L.

Hosseini, H.; Dolatabadi, R.; Shekarchi, M.; Kehavrz, A.; Eskandari, S. and Pirali-Hamedani, M. (2009): Evaluation of histamine Canned Tuna Fish Post Market Samples in Iran using ELISA. Asian Journal of Chemistry. 21: 8, 6429-6434.

ICMSF (1980): Microbial Ecology of Food, Vol. 2: Food Commodities. New York and London, Academic Press. PP. 1-33.

Ismail, H.M. (2005): The role of omega -3 fatty acids in cardiac protection: on overview. Front. Biosci., 10: 1079-1088.

Jarvinen, R.; Knekt, P.; Rissanen, H. and Reunanen, A. (2006): Intake of fish and long chain $\mathrm{n}-3$ fatty acids and the risk of coronary heart mortality in men and women. Br. J. Nutr., 95: 229-824.

Kaitaranta, J.K. (1982): Hydrolytic changes min the lipid of fish product during storage. J. Food Technol. 17: 78-98.

Karl, H.W. (2005): Our Food Database and Related Sciences. Available online http://www.Ourfood.com/introduction.html.

Kassem, G.M.A. (1996): Health hazard due to marketed salted fishes. M.V.Sc. Thesis (meat hygiene) Fac. Vet. Med. Cairo University.

Kirkwood, B.R. (1989): Essentials of Medical Statistics, Blackwell Scientific Publication. $2^{\text {nd }}$ Ed. P. 151.

Krieg, N.R. and Holt, J.G. (1984): Bergey's Manual of Systematic Bacteriology Vol. 1. Baltimore, Williams and Wilkins Co.

Kris-Etherton, P.; Harris, W.S. and Appel, L.J. (2002): Fish consumption, fish oil. Omega-3 fatty acids and cardiovascular disease. Circulation 106: 2747-2757.

Mousa, M.I. (1986): Microbiology of some fish and shell fish in local markets and its relation to Public Health. Ph.D. Thesis, Faculty of 
Veterinary Medicine, Alex. University.

Novotny, L.; Dorska, L.; Lorencova, A.; Beran, V. and Pavlik, I. (2004):

Fish a potential source of bacterial pathogens for human beings Review Article. Vet. Med.- Czech, 49(9):n 343-358.

Peconek, J.; Szczawinski, J.; Fonberg-Broczek, M. and Sawilska, A. (1997): Halophilic bacteria in decarboxylation of histidine in salted fish. Rocz Panstw Zakl Hig, 48(3): 304

Rahman, M.M.; Bhattacharya, A. and Fernandes, G. (2008): Docosahexaenoic acid is more potent inhibitor of osteoclast differentiation in RAW 264.7 cells than eicosapentaenoic acid. J. Cell Physiol., 214: 201-209.

Rakha, M.A. (1992): An outbreak of botulism intoxication due to salted fermente fish (fesiekh). Paper presented at the Expert Consolation on Fish Technology. Alexandeia, Egypt.

Riad, R.M. (1997): Biogenic histamine in salted fish. Ph.D. Thesis (Meat hygiene). Fac. Vet. Med. Assuit Univ.

Rodriguez-Jerez, J.J.; Mora-Ventura, M.T.; Lobez-Saatter, E.I. and Hernandez-Herrero, M. (1994): Histadine, Lysine, ornithin decarboxylase bacteria in Spanish salted semipreserved Anchouvies. J. Food Protect. 57 (9): 789-795.

Samaha, I.A.; Elgazzar, M.M. and El-Atabany, A.I. (1997): Histamine content in Sardine and its products. J. Egypt. Pub. Health Assoc. $(5,6): 471-478$.

Sofas, J.N. (1994): Microbial Growth and its Control in Meat Poultry and Fish . pp. 359. Advances in Meat Research. 1st Ed. Blackie Academic and Professional Champion and Hall. New York.

Taylor, S.L.; Stratton, J.E. and Nordlee, J.A. (1989): Histamine poisoning (Scombroid Fish Poisoning): An allergy-like intoxication. Clin. Toxicol. 27(4-5): 225-240.

Wen, Q. and Maciane, B.A. (2004): Detection of enterotoxigenic clostridium perferingens type $\mathrm{A}$ isolates in American Retail foods. Appl. Environ. Microbial. 70 (5): 268-291. 